\title{
Natural Enemies of Sorghum Shoot Fly, Atherigona soccata Rondani (Diptera: Muscidae)
}

\author{
B. U. SINGH AND H. C. SHARMA \\ Germplasm Resources and Enhancement Program, International Crops Research \\ Institute for the Semi-Arid Tropics (ICRISAT), Patancheru 502 324, Andhra \\ Pradesh, India
}

(Received for publication 18 July 2000; revised manuscript accepted 24 November 2001)

The sorghum shoot fly, Atherigona soccata is one of the most important pests of grain sorghum in Asia, Africa and the Mediterranean Europe. This paper reviews the current state of information on diversity, ecobiology, parasitism levels, and mass rearing of the parasitoids, predators and pathogens attacking different stages of A. soccata. Among the parasitoids, Trichogramma chilonis Ishii and Trichogrammatoide a simmondsi Nagaraja on the eggs, and Neotrichoporoides nyemitawus Rohwer on the larvae are most important. Although 15 species of predators have been recorded, their predation potential has not been assessed under field conditions. Several species of spiders are important predators on eggs. The ecobiology of T. chilonis, T. simmondsi, N. nyemitawus, Spalangia endius Walker and Trichopria sp. has been studied in considerable detail. The parasitism levels are quite high during the post-rainy season by Aprostocetus $s p$., N. nyemitawus, Opius $s p$. and S. endius. Augmenting populations of $\mathrm{T}$. chilonis does not reduce the shoot fly infestation under field conditions. Parasitism by $\mathrm{N}$. nyemitawus is greater in sorghum-cowpea intercrop than where sorghum is the sole crop. Mass rearing techniques are available only for $\mathrm{T}$. chilonis and $\mathrm{T}$. bactrae. The constraints and challenges for utilizing the natural enemies in integrated pest management have been discussed.

Keywords: shoot fy, Atherigona soccata, natural enemies, biological control, sorghum, Trichogramma, Trichogrammatoide a, Neotrichoporoide s nyemitawus

\section{INTRODUCTION}

Sorghum (Sorghum bicolor (L.) Moench) is a major food crop for millions of people in the semi-arid tropics. It is primarily grown under subsistence farming conditions, and the average grain yield is $0.5-0.9 \mathrm{t} \mathrm{ha}^{-1}$ (FAO, 1999). However, many of the high yielding cultivars have the potential to yield $>10 \mathrm{t} \mathrm{ha}^{-1}$. It is cultivated under diverse agroecosystems, and grain yields are influenced by various biotic and abiotic factors. Among the biotic factors, arthropods constitute a major constraint to the increase of sorghum production. 
Over 150 insect species have been reported to damage sorghum in different agroecosystems (Reddy \& Davies, 1979; Jotwani et al., 1980). Among them, the shoot fly (Atherigona soccata Rondani) (Diptera: Muscidae) is one of the most important and destructive pests at the seedling stage. It is widely distributed in tropical and subtropical areas of southeast Asia, Africa, Mediterranean Europe, and the middle East (CIE, 1973). It has not yet been recorded from Australia and the Americas, although a shoot fly species has been found to infest the sorghum crop in Australia (Sharma, H.C., 1997, unpublished).

The eco-biology of $A$. soccata has been reviewed extensively (Jotwani \& Young, 1972; Odhiambo, 1981; Delobel, 1984). Adults oviposit at early dawn, and each female lays up to 75 eggs. The eggs are cigar-shaped, laid singly on the abaxial leaf surface between the first and fourth week after seedling emergence. The eggs hatch in 1-2 days. After eclosion, the larva moves to the growing point through the leaf sheath, and cuts the growing point, resulting in wilting and drying of the central leaf, known as a 'deadheart'. The larva feeds on the decaying plant tissue in the shoot. There are 4-5 instars, and the larval development is completed in 8-10 days. Pupation occurs either at the base of the damaged seedling or in the soil. The pupal period lasts for 5-7 days. Adults survive for 12 days on sorghum seedlings (Barry, 1972a,b). The life-cycle from egg-to-adult is completed in 17-21 days, but can be as long as 45 days, with up to 10 generations per year. Early crop infestation may result in loss of plant stand. Shoot fly infestations generally promote the development of side-tillers after the main shoot is killed. Some of the side-tillers produce productive panicles, which often are subjected to the ravages of panicle feeding insects and birds.

Nearly $32 \%$ of the sorghum crop is lost due to insect pests in India (Borad \& Mittal, 1983), of which $5 \%$ of the loss has been attributed to sorghum shoot fly (Jotwani, 1982, 1983). Total plant stand loss is not uncommon in delayed sorghum plantings in India (Sharma, 1968). Annual losses have been estimated to exceed US\$100 million (ICRISAT, 1992). The economic threshold levels (ETLs) vary over cultivars, locations, and seasons, and are influenced by variation in input costs, value of produce, productivity potential of the crop, as well as other socioeconomic factors. The ETLs have been estimated to be $4-10 \%$, $3-9 \%$ and $6-15 \%$ deadheart incidence in sorghum cultivars CSH 1, CSH 5 and Swarna (CSV 1), respectively, in India (Rai et al., 1978). However, there can be a considerable compensation in grain yield by productive tillers in the damaged plants under high input conditions. Increase in deadhearts by $1 \%$ leads to 89.1 and $30.5 \mathrm{~kg} \mathrm{ha}^{-1}$ reduction in grain yield in CSH 5 and M 35-1, respectively (Mote, 1986).

In India, the shoot fly has attained the status of a principal pest because of the introduction of improved sorghum varieties and hybrids susceptible to this insect, continuous cropping, ratooning, and reduced genetic variability (Singh \& Rana, 1986). Further, its high fecundity and shorter generation span result in rapid population buildup. It is also able to feed on several other plant species including other cereal crops and weeds (Davies \& Seshu Reddy, 1980). In view of its effects on plant stand and loss in grain yield, considerable research efforts have been made to develop strategies for the management of this pest.

Methods currently used to manage sorghum shoot fly during the rainy season include early planting, increased seed rate, thinning and destroying the seedlings with deadhearts, seed treatment or soil application of carbofuran, intercropping sorghum with leguminous crops, crop rotations, and fallowing. Although chemical control with systemic insecticides provides good control, it is not accessible to majority of the small-scale farmers. Thus, host plant resistance can play a vital role in containing shoot fly infestations. However, agronomically acceptable sorghum cultivars with adequate levels of resistance to shoot fly are not available. In such circumstances, natural enemies can play a significant role to suppress $A$. soccata population s below the economic threshold levels.

There is a considerable diversity of natural enemy fauna on shoot fly eggs (Deeming, 1971; Pont, 1972; Taley \& Thakare, 1979; Delobel \& Lubega, 1984; Zongo, 1992, 1995), larvae (Kundu et al., 1971a-c; Kishore et al., 1977a,b; Pont, 1972; Taley \& Thakare, 1979; Delobel \& Lubega, 1984; Zongo, 1992, 1995) and pupae (Deeming, 1971; Taley \& Thakare, 
TABLE 1. Natural enemies of sorghum shoot fly, Atherigona soccata reported from different countries

\begin{tabular}{|c|c|c|c|c|c|c|c|c|}
\hline \multirow[b]{2}{*}{ Country } & \multicolumn{3}{|c|}{ Parasites } & \multicolumn{3}{|c|}{ Predators } & \multirow{2}{*}{$\frac{\text { Pathogens }}{\text { Egg }}$} & \multirow[b]{2}{*}{ Total } \\
\hline & Egg & Larva & Pupa & Egg & Larva & Pupa & & \\
\hline Burkina Faso & 2 & 3 & 1 & 5 & - & - & 2 & 13 \\
\hline India & 7 & 21 & 2 & - & 1 & - & - & 31 \\
\hline Italy & 1 & - & 1 & - & - & - & - & 2 \\
\hline Kenya & 1 & 1 & - & 4 & - & - & - & 6 \\
\hline Morocco & - & 4 & - & - & - & - & - & 4 \\
\hline Nigeria & 1 & 3 & 2 & - & - & - & - & 6 \\
\hline Pakistan & - & - & - & 5 & - & - & - & 5 \\
\hline Thailand & - & 3 & - & - & - & - & - & 3 \\
\hline Uganda & - & - & - & - & - & 1 & - & 1 \\
\hline
\end{tabular}

1979), including spiders (Reddy \& Davies, 1979; Delobel \& Lubega, 1984). The diversity of natural enemies varies widely across the geographic regions (Table 1). Most of the literature reports have only listed the natural enemies recorded on this insect (Gilstrap, 1980; Young, 1981; Zongo, 1995). The primary objective of this review is to summarize the information on the diversity, ecobiology, parasitism levels, and mass rearing techniques of the natural enemies of $A$. soccata, and to assess the potential for strengthening research on promising natural enemies.

\section{EGG PARASITOIDS}

\section{Diversity}

Egg parasitoids of sorghum shoot fly belong to the genera Trichogramma and Trichogrammatoidea. Five species (Trichogramma sp., T. bactrae Nagaraja from India and Burkina Faso; Trichogramma chilonis Ishii and T. japonicum Ashmead from India) (Taley \& Thakare, 1979); T. evanescens Westwood from Nigeria (Deeming, 1971), Burkina Faso (Breniere, 1972) and Italy (Del Bene, 1986), and T. kalkae Sch. \& Feij. from Kenya (ICIPE, 1982; Delobel \& Lubega, 1984) are known to parasitize the eggs of sorghum shoot fly. Trichogramma chilonis was earlier described as T. australicum Girault or T. confusum Viggiani, which are synonyms to T. chilonis (Nagarkatti \& Nagaraja, 1977, 1979). Of the two species of Trichogrammatoidea; T. bactrae Nagaraja (Jai Rao et al., 1987), and T. simmondsi Nagaraja from India (Taley \& Thakare, 1979), and Burkina Faso (Zongo, 1992; Zongo et al., 1993b) have been recorded on the eggs of shoot fly (Table 2). Some of these species have also been reported from eggs of other insect hosts. However, the most important and well studied egg-parasitoids, T. chilonis and T. simmondsi are considered as important mortality factors for $A$. soccata.

\section{Ecobiology}

Both T. chilonis and T. simmondsi are endo-parasitoids of shoot fly eggs. The life cycle of T. chilonis has not been studied fully due to short incubation period. The larvae are immobile in the host egg fluid and pupate in situ. On emergence, the parasitoid stays for 3-5 min on the host egg shell. The total life-cycle is completed in 7-10 days. The male-to-female ratio is $1: 3$ (Table 3 ).

In a sample of 305 eggs, Zongo et al. (1993b) observed one exit hole in $44.9 \%$ eggs, two in $53.5 \%$, and three in $1.6 \%$, which indicates super-parasitism by $T$. simmondsi. Similarly, fewer eggs with two exit holes and high rate of parasitism $(73 \%)$ have been recorded in $<24 \mathrm{~h}$ old eggs of $A$. soccata compared with parasitism in $>24 \mathrm{~h}$ old eggs by $T$. simmondsi. Two days after parasitism, the shoot fly eggs become opaque because of $T$. simmondsi larval development. The duration of development from egg-to-adult emergence is 7-12 days.

The life cycle from the egg-to-adult emergence of $T$. simmondsi usually takes an average 
TABLE 2. Parasitoids of the sorghum shoot fly, Atherigona soccata recorded in different countries

\begin{tabular}{|c|c|c|c|c|}
\hline Order/Family & Parasitoid & Host stage & Country & Reference \\
\hline \multicolumn{5}{|l|}{ Diptera } \\
\hline Muscidae & Acritochaeta orientalis Schiner & Larva & Nigeria & Adesiyun, 1981 \\
\hline Phoridae & Megaselia scalaris Loew. & Larva & Nigeria & Adesiyun, 1981 \\
\hline \multicolumn{5}{|l|}{ Hymenoptera } \\
\hline \multirow[t]{8}{*}{ Braconidae } & Alysia sp. & Pupa & Burkina Faso & Zongo et al., 1993a \\
\hline & & & India & Taley \& Thakare, 1979 \\
\hline & & & Nigeria & Deeming, 1971 \\
\hline & Bracon sp. & Larva & Burkina Faso & Zongo et al., 1993d \\
\hline & Bracon greeni (Ashmead) & Larva & India & AICSIP, 1979 \\
\hline & Opius sp. & Larva-pupa & India & Taley \& Thakare, 1979 \\
\hline & Trichosteresis Gen. near Alysia & Pupa & Nigeria & Deeming, 1971 \\
\hline & $\begin{array}{l}\text { Trichosteresis sp. nr. Foersteri } \\
\text { Kieffer }\end{array}$ & Larva & India & $\begin{array}{l}\text { Pont, 1972; Kundu } \\
\text { et al., 1971a,b; Taley, } \\
\text { 1978; Taley \& Thakare, } \\
1979\end{array}$ \\
\hline Chalcididae & Hockeria sp. & Larva & Burkina Faso & Zongo et al., 1993a \\
\hline \multirow[t]{2}{*}{ Chloropidae } & $\begin{array}{l}\text { Scoliopthalmus micantipennis } \\
\text { Duda }\end{array}$ & Larva & Burkina Faso & Zongo et al., 1993a \\
\hline & Scoliopthalmus nicans Lamb. & Larva & India & Chopde, 1978 \\
\hline \multirow[t]{7}{*}{ Diapriidae } & Monelta sp. & Larva & India & $\begin{array}{l}\text { Taley \& Thakare, } 1977, \\
\text { 1979; Taley, } 1978\end{array}$ \\
\hline & Odonteucoila sp. & Larva & India & $\begin{array}{l}\text { AICSIP, 1976; Shivpuje, } \\
\text { 1977; Chopde, } 1978\end{array}$ \\
\hline & Psilus sp. & Larva & India & Kishore et al., 1977a,b \\
\hline & & & Thailand & Thongsanga, 1985 \\
\hline & Trichopria sp. & Larva & India & $\begin{array}{l}\text { Taley \& Thakare, 1977, } \\
\text { 1979; Taley, 1978, } 1979\end{array}$ \\
\hline & & & Morocco & $\begin{array}{l}\text { Bleton \& Fieuzet, 1939, } \\
1943\end{array}$ \\
\hline & & & Thailand & Thongsanga, 1985 \\
\hline Encyrtidae & Exoristobia deemingi Subbarao & Pupa & Nigeria & Deeming, 1971 \\
\hline \multirow[t]{3}{*}{ Eucoilidae } & $\begin{array}{l}\text { Eucoila haywardi } \mathrm{L} . \\
\text { (Ganaspis haywardi) }\end{array}$ & Larva & India & $\begin{array}{l}\text { AICSIP, 1976, 1979; } \\
\text { Shivpuje, 1977; Kishore } \\
\text { et al., 1977a,b; Jotwani, } \\
\text { 1978; Chopde, } 1978\end{array}$ \\
\hline & Rhoptromeris sp. & Larva & India & $\begin{array}{l}\text { Taley \& Thakare, 1977, } \\
\text { 1979; Taley, 1978, } 1979\end{array}$ \\
\hline & Trichoplasta Benoit sp. & Pupa & Italy & Del Bene, 1986 \\
\hline \multirow[t]{7}{*}{ Eulophidae } & Aprostocetus sp. & Larva & India & $\begin{array}{l}\text { Kundu et al., 1971a,b; } \\
\text { Kishore et al., 1977a,b; } \\
\text { Jotwani, 1978; AICSIP, } \\
\text { 1979, 1980; Taley \& } \\
\text { Thakare, 1979 }\end{array}$ \\
\hline & Crataepiella sp. & Larva-Pupa & India & $\begin{array}{l}\text { Kishore et al., 1977a,b; } \\
\text { Jotwani, } 1978\end{array}$ \\
\hline & Diaulinopsis sp. & Larva & India & $\begin{array}{l}\text { AICSIP, 1976; Kishore } \\
\text { et al., 1977a,b; Jotwani, } \\
1978\end{array}$ \\
\hline & Eupelmus australiensis Girault & Larva & India & AICSIP, 1976, 1979 \\
\hline & Gronotoma sp. & Larva & India & AICSIP, 1979 \\
\hline & $\begin{array}{l}\text { Hemiptarsenus semialbiclavus } \\
\text { (Gir.) }\end{array}$ & Larva & India & $\begin{array}{l}\text { AICSIP, 1976; Kishore } \\
\text { et al., 1977a,b; Jotwani, } \\
1978\end{array}$ \\
\hline & $\begin{array}{l}\text { Neotrichoporoides sp. } \\
\text { (Tetrastichus } \mathrm{sp} .)\end{array}$ & Larva-Pupa & India & $\begin{array}{l}\text { Rohwer, 1921; Raodeo } \\
\text { et al., 1972; AICSIP, } \\
\text { 1976, 1979, 1980, 1987; } \\
\text { Kishore et al., 1977a,b; } \\
\text { Taley \& Thakare, 1979; } \\
\text { Reddy \& Davies, } 1979\end{array}$ \\
\hline
\end{tabular}


TABLE 2. Continued

\begin{tabular}{|c|c|c|c|c|}
\hline Order/Family & Parasitoid & Host stage & Country & Reference \\
\hline \multirow{9}{*}{ Ichneumonidae } & $\begin{array}{l}\text { Neotrichoporoides nyemitawus } \\
\text { Rohwer }\end{array}$ & Larva-Pupa & Burkina Faso & $\begin{array}{l}\text { Zongo, 1992; Zongo } \\
\text { et al., 1993c }\end{array}$ \\
\hline & $\begin{array}{l}\text { (Tetrastichus nyemitawus } \\
\text { Rohwer) }\end{array}$ & & India & $\begin{array}{l}\text { Rohwer, 1921; Rawat \& } \\
\text { Sahu, 1968; Raodeo } \\
\text { et al., 1972; AICSIP, } \\
\text { 1979, 1980, 1987; Reddy } \\
\text { \& Davies, 1979 }\end{array}$ \\
\hline & & & Kenya & $\begin{array}{l}\text { ICIPE, 1982; Delobel \& } \\
\text { Lubega, } 1984\end{array}$ \\
\hline & & & Thailand & $\begin{array}{l}\text { Meksongsee et al., } \\
\text { 1981; Thongsanga, } 1985\end{array}$ \\
\hline & Diplazon bizonarius Gravenhorst & Larva & India & Kundu et al., 1971a,b \\
\hline & $\begin{array}{l}\text { (Homocidus bizonarius } \\
\text { Gravenhorst) }\end{array}$ & & Morocco & $\begin{array}{l}\text { Bleton \& Fieuzet, 1939, } \\
1943\end{array}$ \\
\hline & Phygadeuon sp. & Larva & Morocco & $\begin{array}{l}\text { Bleton \& Fieuzet, 1939, } \\
1943\end{array}$ \\
\hline & Pimplomorpha sp. & Larva & Nigeria & Adesiyun, 1981 \\
\hline & $\begin{array}{l}\text { Syrphophilus bizonarius } \\
\text { Gravenhorst }\end{array}$ & Larva & Morocco & $\begin{array}{l}\text { Bleton \& Fieuzet, 1939, } \\
1943\end{array}$ \\
\hline \multirow[t]{3}{*}{ Pteromalidae } & Callitula spp. & Larva & India & $\begin{array}{l}\text { Kundu et al., 1971b; } \\
\text { Kishore et al., 1977a; } \\
\text { Jotwani, 1978 }\end{array}$ \\
\hline & Callitula bipartitus Farooqui & Larva & India & Kundu et al., 1971c \\
\hline & Spalangia endius Walker & Larva & India & $\begin{array}{l}\text { Taley \& Thakare, } 1977, \\
\text { 1979; Taley, 1978, } 1979\end{array}$ \\
\hline \multirow[t]{12}{*}{ Trichogrammatidae } & Trichogramma spp. & Egg & India & $\begin{array}{l}\text { Pont, 1972; Taley \& } \\
\text { Thakare, } 1979\end{array}$ \\
\hline & & & Nigeria & Deeming, 1971 \\
\hline & T. bactrae Nagaraja & Egg & Burkina Faso & $\begin{array}{l}\text { Zongo, 1992, 1995; } \\
\text { Zongo et al., 1993b }\end{array}$ \\
\hline & $\begin{array}{l}\text { T. chilonis Ishii. } \\
\text { (T. australicum Girault) } \\
\text { (T. confusum Viggiani) }\end{array}$ & Egg & India & $\begin{array}{l}\text { Taley, 1978, 1979; } \\
\text { Jotwani, 1978; Taley \& } \\
\text { Thakare, 1979; AICSIP, } \\
\text { 1986, } 1987\end{array}$ \\
\hline & T. evanescens Westwood & Egg & Italy & Venturi, 1940 \\
\hline & & & Nigeria & Deeming, 1982 \\
\hline & & & Upper Volta & Breniere, 1972 \\
\hline & T. japonicum Ashmead & Egg & India & ICRISAT, 1980, 1982 \\
\hline & T. kalkae Sch. \& Feij. & Egg & Kenya & $\begin{array}{l}\text { ICIPE, 1982; Delobel, } \\
1984\end{array}$ \\
\hline & Trichogrammatoidea $\mathrm{sp}$. & Egg & India & ICRISAT, 1982 \\
\hline & T. bactrae & Egg & Burkina Faso & $\begin{array}{l}\text { Zongo, 1992; Zongo } \\
\text { et al., 1993a,d }\end{array}$ \\
\hline & T. simmondsi Nagaraja & Egg & India & $\begin{array}{l}\text { AICSIP, 1986, 1987, } \\
1989\end{array}$ \\
\hline
\end{tabular}

of 9.8 days on the eggs of $A$. soccata at $26^{\circ} \mathrm{C}$ (Zongo et al., 1993b), and 11 days on the eggs of rice stalk-eyed fly, Diopsis (Macrophthalma Dalm.) thoracica Westwood at $25^{\circ} \mathrm{C}$ (Feijen \& Schulten, 1981) (Table 3). The longevity of adult male and female parasitoids on $A$. soccata is 25.0 and $35.2 \mathrm{~h}$, respectively, with a sex ratio of 1:1.5 (Zongo et al., 1993c), while the female parasitoid survive for 57.6 h on D. thoracica (Feijen \& Schulten, 1981).

\section{Parasitism Levels}

The levels of egg parasitism vary widely across seasons and locations. In Burkina Faso, T. simmondsi was recorded on the sorghum crop between 17 and 38 days after planting. 
TABLE 3. Life-cycle duration, longevity, and sex ratio of parasitoids recorded on sorghum shoot fly, Atherigona soccata

\begin{tabular}{|c|c|c|c|c|c|c|c|c|c|}
\hline \multirow[b]{3}{*}{ Parasitoid } & \multicolumn{5}{|c|}{ Duration (days) } & \multirow{2}{*}{\multicolumn{2}{|c|}{$\begin{array}{l}\text { Adult longevity } \\
\text { (days) }\end{array}$}} & \multirow{3}{*}{$\begin{array}{c}\begin{array}{c}\text { Sex } \\
\text { ratio }\end{array} \\
\text { Male: } \\
\text { Female }\end{array}$} & \multirow{3}{*}{ Reference } \\
\hline & \multirow{2}{*}{$\begin{array}{c}\text { Egg } \\
\text { incuba- } \\
\text { tion }\end{array}$} & \multirow[b]{2}{*}{ Larva } & \multirow[b]{2}{*}{ Pupa } & \multicolumn{2}{|c|}{ Total life-cycle } & & & & \\
\hline & & & & Mean & Range & Male & Female & & \\
\hline Monelta sp. & - & - & - & - & $20-30$ & - & - & - & Taley \& Thakare, 1979 \\
\hline N. nyemitawus & $2-3$ & $15-20$ & $8-12$ & 21.7 & $25-35$ & - & - & $1: 1.47$ & Zongo et al., 1993c \\
\hline Rhoptromeris sp. & - & - & - & - & $20-30$ & 21.1 & 51.0 & 1.3 & Taley \& Thakare, 1979 \\
\hline S. endius & $2-3$ & $9-12$ & $15-90$ & - & $26-106$ & - & - & $1: 1$ & Taley \& Thakare, 1979 \\
\hline Trichopria $\mathrm{sp}$ & - & - & - & - & $24-44$ & - & - & $1: 3$ & Taley \& Thakare, 1979 \\
\hline T. chilonis & - & - & - & - & $7-10$ & - & - & $3: 1$ & Taley \& Thakare, 1979 \\
\hline T. simmondsi & - & - & - & 9.8 & $\begin{array}{c}7-12 \\
(22-26)\end{array}$ & $\begin{array}{c}25.0 \\
(25-50)\end{array}$ & 35.2 & $1: 1.28$ & Zongo et al., 1993c \\
\hline
\end{tabular}

Although 8.8 and $12.3 \%$ egg parasitism was recorded in two consecutive years in sorghumcowpea intercrop, no significant differences were observed between sorghum and sorghumcowpea intercrop (Zongo et al., 1993a).

Inundative releases of $T$. chilonis at weekly intervals, over a period of 3 weeks, starting with first appearance of eggs of $A$. soccata did not give consistent results on parasitism of shoot fly eggs (AICSIP, 1997). The parasitoids T. chilonis and T. simmondsi also have several alternate hosts such as spotted stem borer, Chilo partellus Swinhoe, Helicoverpa armigera Hub., and Mythimna separata Walk. in sorghum; and C. partellus, Sepedon sp. (Diptera: Sciomyzidae), and the rice stalk-eyed fly, D. thoracica in rice for T. chilonis in India (Nagaraja, 1978), and D. thoracica in rice for T. simmondsi in Malawi (Feijen \& Schulten, 1981) and India (Nagaraja, 1978). Numbers of exit holes (1,2, and 3) by T. simmonds; on each shoot fly egg have been observed in the proportion of $44.9 \%, 53.5 \%$ and $1.6 \%$, respectively, indicating super-parasitism (Zongo et al., 1993a).

\section{Mass Rearing}

Techniques for mass rearing of Trichogramma spp. and Trichogrammatoidea spp. have been developed. In many countries, they are usually reared on eggs of the factitious host, Corcyra cephalonica Stainton (Lepidoptera: Pyralidae). Before exposure to the parasitoids, C. cephalonica eggs are killed by either UV irradiation (Maninder \& Varma, 1980; Singh et al., 1994), or chilling at $-5^{\circ} \mathrm{C}$ for $48 \mathrm{~h}$, but the chilled eggs are significantly less acceptable to T. chilonis than the untreated eggs (Hugar et al., 1990). Parasitized eggs can be stored at $10^{\circ} \mathrm{C}$ for as long as 49 days without affecting the parasitoid survival (Jalali \& Singh, 1992). Several constraints to mass rearing of $T$. chilonis have been reported. Laboratory-reared females have shown a significantly higher degree of sterility than those collected from the field (Nagarkatti \& Nagaraja, 1978), and laboratory-reared populations are more sensitive to both high and low temperatures than the wild-types (Nagarkatti, 1979). In searching for better field-adapted strains, T. chilonis population s collected from different habitats and locations were compared by Mandal and Somchoudhury (1991) and Jalali and Singh (1993). They found variability in morphometrics and biological attributes such as the number of host eggs parasitized per female and adult longevity. Abraham and Pradhan (1976) attempted to select a $T$. chilonis strain adapted to high temperatures and low humidity, but without much success.

Another egg parasitoid, T. bactrae, has been successfully reared on C. cephalonica eggs (Jai Rao et al., 1980). 


\section{LARVAL PARASITOIDS}

\section{Diversity}

The larval stadia of shoot fly are attacked by a diverse group of parasitoids, but their impact is usually too little to influence shoot fly population dynamics since the larvae feed inside the shoot in a protected environment. The larval parasitoids belong to Muscidae and Phoridae in Diptera; and Braconidae, Ceraphrontidae, Chalcididae, Chloropidae, Diapriidae, Eucoilidae, Eulophidae, Ichneumonidae and Pteromalidae in Hymenoptera (Table 2). The endo-larval parasites, Neotrichoporoides sp. and N. nyemitawus Rohwer have been studied extensively in India (Raodeo et al., 1972), and Burkina Faso (Zongo, 1992; Zongo et al., 1993c).

\section{Ecobiology}

Neotrichoporoides nyemitawus was first recorded on sorghum shoot fly at Coimbatore, Tamil Nadu, India and described as Tetrastichus nyemitawus (Rohwer, 1921). Subsequently, it was reported from Maharashtra (Raodeo et al., 1972), Delhi (Kishore et al., 1977a,b), and Andhra Pradesh in India (Reddy \& Davies, 1979), Thailand (Meksongsee et al., 1981; Thongsanga, 1985), Kenya (ICIPE, 1982; Delobel \& Lubega, 1984), and Burkina Faso (Zongo, 1992). In a revision of the European Tetrastichinae (Hymenoptera: Eulophidae), Graham (1987) replaced the genus Tetrastichus by Neotrichoporoides Girault. The searching behavior of $N$. nyemitawus has been studied by Zongo et al. (1993c), and categorized into four phases: exploration, ovipositor insertion, oviposition, and resting. The female parasitoid uses its antennae to explore the sorghum seedlings, and inspects the leaves adjacent to the point of leaf whorl and sometimes enters the central whorl to detect the presence of shoot fly larvae. After locating the shoot fly larvae inside the seedling, the parasitoid moves the ovipositor around the sorghum seedling several times (8-123 times) till it finds a suitable penetration site, and then inserts the ovipositor into the plant tissues. The exploration and oviposition after seedling penetration usually take about $10 \mathrm{~min}$. During the oviposition process, the female holds the seedling with its legs, and upper leaves are used for resting. Usually a single egg is laid in each shoot fly larvae between the VII and VIII abdominal segment, but two eggs per larva have also been observed (1 in 30 samples). The lack of attraction to the first instar, and high and low per cent parasitism of second and third instars, respectively, suggests that the size of shoot fly larva is used as physical cue by the females for oviposition. After parasitism, the $A$. soccata larva dies in 5.1 days. The deadheart is caused mainly by the first instar larval feeding within 1-3 days after reaching the growing point (Raina, 1981). Therefore, the deadheart formation cannot be avoided before or after shoot fly larvae are parasitized. Maximum longevity of the adult female parasitoid is 51 days. Neotrichoporoides nyemitawus is an internal larval parasite, and the egg incubation period is 2-3 days. The larva passes through four instars, and takes about 15-20 days to complete the development. When the parasitoid larva reaches the third-instar, it makes the host larva inactive, and completely diseased (Taley \& Thakare, 1979). The pupal period lasts for 8-12 days. The total life-cycle takes 24-35 days, and the sex ratio is 1:3. The average life span of $N$. nyemitwus adult males and females is 21.7 and 51.0 days, respectively (Taley \& Thakare, 1979).

\section{Parasitism Levels}

Shivpuje and Chopde (1976) recorded Ganaspis sp. and Odonteucoila sp. on shoot fly eggs. Eleven new hymenopterous parasites including $N$. nyemitawus, T. chilonis and Spalangia sp. were studied between 1968 and 1971 by Taley and Thakare (1979). In Udaipur, larval parasitism was found to be 24, 16 and 6\% in September, October and November, respectively, and the predominant parasite was Aprostocetus sp., while only a few specimens of Callitula sp. were collected (Kundu et al., 1971b). Neotrichoporoides sp. and N. nyemitawus emergence 
was observed in September, December, and January at Parbhani, India (Raodeo et al., 1972) (Table 6).

An endo-parasite, Trichoplasta Benoit sp. (Hymenoptera: Eucoilidae), has been recorded from shoot fly pupae in Italy (Del Bene, 1986). In India, Aprostocetus sp., Callitula bipartitus Farooqui, Neotrichoporoides sp., and N. nyemitawus have been recorded from a number of locations. The maximum parasitism was found to be $35.3 \%$ during the first week of August (Jotwani, 1981). A few other parasites recorded from shoot fly include Psilus sp. (Diapriidae), Hemiptarsenus sp., and Diaulinopsis sp. (Eulophidae), and the extent of parasitism ranged between 1 and 4\% (Kishore et al., 1977a,b).

Although $N$. nyemitawus cannot prevent deadheart formation, it may be of potential use in reducing population buildup of shoot fly in the first generation, which is quite low in early plantings. Parasitism levels increase by the second generation, coinciding with delayed plantings during the rainy season (Zongo et al., 1993a,d). Intercropping of sorghum with cowpea has a beneficial effect in increasing the levels of parasitism by $N$. nyemitawus. There was a nearly 2-fold and 1.4-fold increase in larval parasitism (11.8 and 17.5\%) in sorghumcowpea intercrop over monocrop sorghum. Parasitism ranged from $6.0-17.5 \%$ in Burkina Faso (Zongo et al., 1993a); 1.6-8.3\% in Maharashtra (Taley \& Thakare, 1979), 22-30\% in Madhya Pradesh in India (Rawat \& Sahu, 1968) and 37.4\% in Thailand (Thongsanga, 1985). Parasitism by $N$. nyemitawus during October to March has been reported to be $1.6-8.3 \%$.

Other larval parasitoids such as Bracon sp. and Hockeria sp. have also been recorded from shoot fly larvae, but are present in small numbers (Zongo et al., 1993a,d). Hockeria sp. is distributed worldwide and contains 30 described species (Halstead, 1990). The results suggested that $T$. simmondsi was more effective than $N$. nyemitawus in reducing shoot fly populations.

Investigations carried out in India have shown that Aprostocetus sp. may be one of the major parasites of shoot fly (AICSIP, 1977; Jotwani, 1978). At Udaipur, Kundu et al. (1971b) observed up to $60 \%$ parasitism. Subsequently, other parasites such as Callitula sp. (Eucoilidae), Psilus sp. (Diapriidae), Hemiptarsenus sp. and Diaulinopsis sp. (Eulophidae) from Delhi, India (Jotwani, 1978), Scoliopthalmus nicans Lamb. (Chloropidae) from Parbhani, India (Chopde, 1978), and S. micantinpennis Duda from Burkina Faso (Zongo et al., 1993a) have been recorded. Parasitism by Ganaspis sp. and Odonteucoila sp. in October was 2 and 5\%, respectively (Chopde, 1978) (Table 4). More information is needed on the biology and parasitism levels to exploit the full potential of natural enemies for shoot fly control.

TABLE 4. Parasitism levels of sorghum shoot fly, Atherigona soccata recorded in different countries

\begin{tabular}{|c|c|c|c|c|}
\hline \multirow[b]{2}{*}{ Parasitoid } & \multicolumn{2}{|c|}{ Parasitism levels $(\%)$} & \multirow[b]{2}{*}{ Country } & \multirow[b]{2}{*}{ Reference } \\
\hline & Mean & Range & & \\
\hline Aprostocetus sp. & - & $6.0-24.0$ & India & Kundu et al., 1971a \\
\hline Ganaspis sp. & 2.0 & & India & Shivpuje \& Chopde, 1976; Chopde, 1978 \\
\hline Monelta sp. & & $0.9-3.3$ & India & Taley \& Thakare, 1979 \\
\hline \multirow[t]{4}{*}{ N. nyemitawus } & - & $6.0-17.5$ & Burkina Faso & Zongo et al., 1993c \\
\hline & & $1.6-8.3$ & India & Taley \& Thakare, 1979 \\
\hline & & $22.0-30.0$ & India & Rawat \& Sahu, 1968 \\
\hline & 37.4 & & Thailand & Thongsanga, 1985 \\
\hline Odonteucoila sp. & 4.0 & & India & Chopde, 1978 \\
\hline Opius sp. & & $0.3-4.5$ & India & Taley \& Thakare, 1979 \\
\hline Rhoptromeris sp. & & $0.5-4.2$ & India & Taley \& Thakare, 1979 \\
\hline S. endius & - & $8.0-10.6$ & India & Taley \& Thakare, 1979 \\
\hline T. chilonis & - & $20.0-60.0$ & India & Taley \& Thakare, 1979 \\
\hline T. simmondsi & & $7.0-12.3$ & Burkina Faso & Zongo et al., 1993b \\
\hline Trichopria sp. & - & $1.2-5.8$ & India & Taley \& Thakare, 1979 \\
\hline
\end{tabular}




\section{Mass Rearing}

The development of techniques to rear larval parasitoids has largely been focussed on $N$. nyemitawus because of its better parasitism potential as compared to the other parasitoids. The egg-to-adult development was completed in 25 days. The females lay an average of 168 eggs at $27^{\circ} \mathrm{C}$ and 17 eggs at $31^{\circ} \mathrm{C}$ (Taley \& Thakare, 1979). Adults survived on $10 \%$ honey solution for 8 days (Zongo et al., 1993c). The techniques for mass production of N.nyemitawus are still unavailable (Taley \& Thakare, 1979; Zongo et al., 1993c).

\section{PUPAL PARASITOIDS}

\section{Diversity}

Six pupal parasitoids have been recorded on A. soccata from India and Burkina Faso, which include two braconids, an encyrtid, an eucoilid and two eulophids (Table 2). The larvalpupal parasitoids include Spalangia endius Walker, Trichopria sp. and Opius sp. Pupal parasitoids such as Monelta sp., and Rhoptromeris sp. have been reported from Maharashtra, India (Taley \& Thakare, 1979); Alysia sp. from Nigeria (Deeming, 1971), India (Taley \& Thakare, 1979), and Burkina Faso (Zongo et al., 1993a,d), and Crataepiella sp. from Delhi, India (Kishore et al., 1977a,b; Jotwani, 1978), and Trichoplasta Benoit sp. from Tuscany and Lazio, Italy (Del Bene, 1986). Since A. soccata pupates inside the seedlings and occasionally in the soil, pupae are rarely sampled. Therefore, the pupal mortality reported in A. soccata is caused by larval-pupal parasitoids and does not reflect the impact of true pupal parasitoids. However, the pupal parasitoids may also play an important role in population dynamics of sorghum shoot fly.

\section{Ecobiology}

The life cycle of the pupal parasitoid, Trichopria sp. (Hymenoptera: Diapriidae) is completed in 24-44 days. Morphometrics of the egg and larva have been described by Taley and Thakare (1979). Spalangia endius (Hymenoptera: Pteromalidae) inserts the eggs into the body of shoot fly larva or pupa, and the egg incubation period lasts for 2-3 days. There are three larval stadia, which complete development in 9-12 days, and the pupal stage lasts for 15-90 days. The total life cycle from egg-to-adult is completed in 25-106 days, and the sex ratio is $2: 1$. The emergence of $S$. endius in June-July from the pupae collected in February and March indicates hibernation during the pupal stage. Although the life cycle of Opius sp. has not been studied, the emergence of adults from the pupae collected in March and October during June-July and November, respectively, suggests possible aestivation during the pupal stage. Monelta sp. and Rhoptromeris sp. takes 20-30 days for adult emergence (Taley \& Thakare, 1979) (Table 3).

\section{Parasitism}

Parasitism during March by Monelta sp. and Rhoptromeris sp. was 3.3 and 4.2\%, respectively. Higher levels of parasitism by Trichopria sp. have been recorded from February $(1.3 \%)$ to March (1.8-5.8\%). The parasitism levels by S. endius range between 8.0 and $10.6 \%$ in June and October, respectively (Taley \& Thakare, 1979) (Table 3).

\section{PREDATORS}

\section{Diversity}

More than 15 species of arthropods such as coccinellids, formicids, thrips, and spiders have been recorded as predators in sorghum fields on one or more stages of A. soccata (Table 5).

\section{Ecobiology}

Shoot fly eggs are among the most vulnerable to predation. In Burkina Faso, Zongo et al. (1993a) studied the feeding potential of Tapinoma sp. Forster (Formicidae) as a voracious 
TABLE 5. Arthropod predators of sorghum shoot fly, Atherigona soccata recorded in different countries

\begin{tabular}{|c|c|c|c|c|}
\hline Order/Family & Predator & Host & Country & Reference \\
\hline \multicolumn{5}{|l|}{ Coleoptera } \\
\hline \multirow[t]{5}{*}{ Coccinellidae } & Brumoides suturalis F. & Egg & Pakistan & Rahim, 1990 \\
\hline & $\begin{array}{l}\text { Cheilomenes sexmaculata } \mathrm{F} \text {. } \\
\text { (Menochilus sexmaculatus } \\
\text { Fabricius) }\end{array}$ & Egg & Pakistan & Rahim, 1990 \\
\hline & Coccinella septempunctata $\mathrm{L}$. & Egg & Pakistan & Rahim, 1990 \\
\hline & Coccinella undecimpunctata L. & Egg & Pakistan & Rahim, 1990 \\
\hline & Scymnus trepidulus Weise & Egg & Kenya & $\begin{array}{l}\text { ICIPE, 1982; Delobel \& } \\
\text { Lubega, } 1984\end{array}$ \\
\hline \multicolumn{5}{|l|}{ Diptera } \\
\hline Cecidomyiidae & Dicrodiplosis sp. & Egg & Burkina Faso & Zongo et al., 1993d \\
\hline \multicolumn{5}{|l|}{ Hymenoptera } \\
\hline Formicidae & Tapinoma sp. & Egg & Burkina Faso & Zongo et al., 1993d \\
\hline Sphecidae & $\begin{array}{l}\text { Dasyproctus bipunctatus } \\
\text { Lepeletier and Brulle }\end{array}$ & Adult & Uganda & Deeming, 1983 \\
\hline \multicolumn{5}{|l|}{ Thysanoptera } \\
\hline Haplothripinae & Thrips sp. & Egg & Burkina Faso & Zongo et al., 1993d \\
\hline Phlaethripidae & Thrips sp. & Egg & Burkina Faso & Zongo et al., 1993d \\
\hline \multicolumn{5}{|l|}{ Acari } \\
\hline Erythraeidae & Abrolophus sp. & Larva & India & Reddy \& Davies, 1978 \\
\hline \multicolumn{5}{|l|}{ Astigmata } \\
\hline Araneidae & Araneus sp. & Egg & Burkina Faso & Zongo et al., 1993a,d \\
\hline & Spider (unidentified) & Egg & Kenya & Delobel \& Lubega, 1984 \\
\hline Histiotomtidae & Spider (unidentified) & Egg & Burkina Faso & Zongo et al., 1993b \\
\hline Linyphiidae & Meioneta prosectes Locket & Egg & Burkina Faso & Zongo et al., 1993d \\
\hline \multirow[t]{3}{*}{ Lycosidae } & Misumenops sp. & Egg & Burkina Faso & Zongo et al., 1993a,d \\
\hline & Neoscona sp. & Egg & Burkina Faso & Zongo et al., 1993a,d \\
\hline & Pardosa injuncta P.P.Cbr. & Egg & Burkina Faso & Zongo et al., 1993d \\
\hline Salticidae & Spider (unidentified) & Egg & Kenya & Delobel \& Lubega, 1984 \\
\hline Saproglyphidae & Suidisia pontifica Oudemans & Egg & Burkina Faso & Zongo et al., 1993d \\
\hline \multirow[t]{2}{*}{ Theridiidae } & $\begin{array}{l}\text { Latrodectus geometricus C.L. } \\
\text { Koch }\end{array}$ & Egg & Burkina Faso & Zongo et al., 1993d \\
\hline & Steatoda badia Rohwer & Egg & Burkina Faso & Zongo et al., 1993d \\
\hline Thomisidae & Spider (unidentified) & Egg & Kenya & Delobel \& Lubega, 1984 \\
\hline
\end{tabular}

predator of the shoot fly eggs. It consumes up to 18 eggs/day in the laboratory. In addition, the thysanopteran species (Phlaethripidae and Haplothripinae), a cecidomyiid species, Dicrodiplosis sp. and a few mite species of the family Histiotomtidae and Suidasia pontifica Oudemans (Astigmata: Saproglyphidae ) were found in association with shoot fly eggs (7.1 per sample) (Zongo et al., 1993a,d). Reddy and Davies (1979) observed Abrolophus spp. (Acari: Erythraeidae) feeding on eggs and larvae of $A$. soccata in India. Larvae of Dicrodiplosis spp. have also been reported as predators on mealy bugs. More research is needed to draw valid conclusions on the status and predatory potential of these predators for controlling shoot fly population s.

Several unidentified species of spiders from Kenya have been reported as predators on shoot fly eggs (Delobel \& Lubega, 1984). In Uganda, Deeming (1983) reported predation of shoot fly adults by Dasyproctus bipunctatus Lepeletier and Burlle (Hymenoptera: Sphecidae). Forel (1920) mentioned that the genus Tapinoma sp. is widely distributed, but many species are opportunistic nestlers (Holldobler \& Wilson, 1990). Zongo et al. (1993a,d) observed that saltids, thomisids, and aranaeids were predominant in a monocrop of sorghum, but the number of spider species such as Araneus sp., Latrodectus geometricus C.L. Koch (Theridiidae), Meioneta prosectes Locket (Linyphiidae), Misumenops sp., Neoscona sp., Pardosa injuncta P.P.Cbr. (Lycosidae) and Steatoda badia Rohwer (Theridiidae) increased in sorghum-cowpea intercrop. Bailey and Chada (1968) reported that the species belonging to Lycosidae, Thomisidae and Salticidae are common in sorghum crop, and spider population s 
in sorghum fields play a significant role in containing the sorghum insect pests. In view of the increase in spider population fauna by 31 days after crop planting, the period coinciding with the susceptible stage of sorghum to shoot fly, it may be concluded that spider populations play an important role in reducing the shoot fly populations. Zongo et al. (1993a,d) also opined that information on the bionomics of spider species may help to understand the real impact of spiders on shoot fly abundance in sorghum-based cropping systems.

\section{PATHOGENS}

\section{Diversity}

Information on the diversity of pathogens on shoot fly populations is limited. A fungus, Fusarium sp. Link ex Fr. and a bacterium, Corynebacterium sp. Lehmann and Neumann have been isolated from shoot fly eggs (Zongo et al., 1993a,d). However, it may be that inoculum of these pathogens, which usually infects sorghum may persist in the field and contaminate the eggs of shoot fly. Further, the genus Fusarium infects a wide range of insect hosts. Some species such as F. avenaceum Fries Saccardo, and F. merismoides Corola have been recorded on the eggs of Lymantria dispar L. (Humber \& Soper, 1986). Similarly, Corynebacterium species are widely distributed in nature, and some species are associated with insects and birds (Buchanan and Gibbons, 1974).

\section{CHALLENGES AND CONSTRAINTS}

Atherigona soccata continues to be an economically important pest on sorghum in the semiarid tropics. For sustainable sorghum crop production, there is a need to consider the role of natural enemies as a component in integrated management of this species. The seasonal appearance of sorghum shoot fly depends mostly on the rainfall pattern, latitude, cultivar and time of planting. Sorghum is grown as a single season crop in most of the countries, except in India, where shoot fly infestation starts in early June, and during July and August in the north coinciding with the onset of monsoon rains. Although the crop harvest usually destroys the habitat, a small residual population of the natural enemies may survive on low populations of shoot fly on wild grasses, and on tillers from harvested stubble and ratoon sorghums during the off-season. Moreover, the coevolved guilds of natural enemies in some cases have been unable to exploit their host(s) in the ecosystem due to changes in cultivation of commercial cultivars vis-à-vis local landraces during the rainy and postrainy seasons, the canopy architecture or phenology, spread of the crop/cultivars into new areas, adoption of monoculture rather than polyculture production methods, and/or asynchrony between the parasitoid and the host. Thus, the parasitoid s may simply be slow to follow the host.

Although parasitoids and predators are known to attack $A$. soccata at different stages, some of these associations may be incidental, whereby some species may be merely associated with other hosts. Among the egg parasitoids, the genus Trichogramma is most widely distributed in India, Burkina Faso, Kenya, and Thailand. In India, attempts to suppress A. soccata population s by augmenting $T$. chilonis population s have been inconsistent, and economic feasibility has not been demonstrated. Hymenopteran larval parasitoids have been reported on $A$. soccata, but reports on parasitoids that attack the pupal stage are relatively fewer. Although many of the parasitoids have evolved adaptation s to access and exploit concealed larvae and pupae of shoot fly, generally these life-stages have not been sufficiently exploited by the parasitoids to reduce the pest density to below economic threshold levels (ETLs).

Natural enemy abundance and parasitism is highly dependent on location and season. Some parasitoids appear to be restricted to certain geographic areas and may be suitable for redistribution in other areas. Sorghum-based cropping systems are being practiced by 
the farming community in the semi-arid tropics. The influence of these cropping systems in promoting enhanced natural enemy activity needs to be assessed. Of greater importance is the paucity of information concerning the impact of known natural enemies on shoot fly populations in the field, and possible reasons for their failure to maintain $A$. soccata populations below ETLs. Researchers have carried out life-history studies on a few natural enemies to predict their ecological adaptability to aid in developing mass-rearing methods. There still is a need for identification and introduction of potential natural enemies, and also examine the possibilities for manipulating the sorghum-based cropping systems to enhance the impact of natural enemies, conserve the natural enemy fauna by synchronizing their seasonal abundance with that of the pest, establish the natural enemy population required per unit area, and study the economic impact of the natural enemies under subsistence farming. Life table studies have not been carried out on the population dynamics and survival rates of $A$. soccata. Gilstrap (1985) indicated the lack of intensive studies on the role of natural enemies on wild host plants of shoot fly. It has been suggested that the natural enemy diversity and enhancement of their efficacy through suitable sorghum-based cropping systems are the prerequisites without which their prospects cannot be assessed accurately for development and implementation of appropriate management strategies (Bellows et al., 1992). Climatically comparable locations and those with similar habitats may harbor natural enemies with best ability for successful control of sorghum shoot fly.

Existence of a parasite in a natural habitat is most important, and success of associations follow a sequence of events by which the natural enemies utilize the host for development and survival. These events include: habitat selection, host-finding, and the behavioral aspects of the host, including the physiologica 1 aspects of host acceptance, host suitability, and host regulation. However, little attention has been paid to behavioral aspects. Cues associated with these processes are mainly derived from the sorghum seedlings, the microhabitat, and the host plant reaction to insect attack. There is a need to conduct studies on tritrophic interactions involving the host genotypes, natural enemy, and the environment, to understand the factors affecting the ecobiology and performance of natural enemies. The biology of most of the predators is unknown and their role in regulating A. soccata populations, individually or as a group, has not been quantified. There has been relatively little research effort on shoot fly predators due to the enormous amount of samples required, and the sampling time to produce quantitative data.

Among the natural enemies recorded, 11 species of insects, and several species of spiders predate on the eggs, larvae, and pupae of A. soccata. Deeming (1971) observed that the solitary larvae of Scoliopthalmus micantipennis Duda destroy young sorghum seedlings. But, Zongo (1992) reported that a dozen of S. micantipennis larvae are associated with $A$. soccata larvae in the same infested seedling. Similarly, the larvae of certain chloropids, Anatrichus erinaceum Loew., Elachipterus abessynicus Becker; a diopsid, Diopsis sp.; a phorid, Megaselia scalaris F. and a muscid, Acritochaeta orientalis Schiner have also been found in the infested seedlings along with sorghum shoot fly larvae, and it may be that the A. soccata damaged sorghum seedlings are more attractive to these insects (Gahukar, 1985; Doumbia \& Gahukar, 1986). From a two-year study, Zongo et al. (1993a) reported highest percentages of larval parasitism by $N$. nyemitawus at 31 and 38 days after planting in monocrop sorghum and sorghum-cowpea intercrops, respectively.

Aprostocetus spp. have been recorded parasitizing eggs, larvae, and pupae of several species of Diptera, Hemiptera, and Coleoptera (e.g., eggs of Tragocephala sp. by A. near diplosidis Crwf. in West Africa) (Smith, 1961), Conchyloctenia (Aspidomorpha) punctata parumaculata (Boh.) by A. aspidomorpha Ferriere in Kenya (Maitai, 1958), and larvae of sorghum midge, Stenodiplosis sorghicola Coq. in East Africa (Geering, 1953); larvae and pupae of rice stem borer, Pachylophus sp. by A. dioprisi Risbec in Cameroon (Descamps, 1957), and grubs of amaranthus weevil, Lixus truncatulus Fab. by A. krishnieri Mani in India (Mani, 1941). Therefore, Aprostocetus sp. might play an important role in biological control of insects in sorghum. Similarly, Callitula bicolor Spin. has been recorded parasitizing 
the pupae of different species of frit fly viz., Oscinella frit Linn., O. minor L., and $O$. carbonaria L. in North America, and larvae of $O$. frit in Westphalis (Hemer, 1960). The spider, Suidisia pontifica Oudemans is associated with shoot fly eggs (Zongo et al., 1993d), but earlier reports suggested that it is mycophagous (due to variable degrees of selectivity in choosing fungi) (Sinha, 1966). Thus, there may be misconception about their predatory nature on shoot fly eggs.

Recovery of parasitoids from immature stages presents different challenges. Rearing of immature stages of the parasitoids requires suitable growth stages of $A$. soccata in sorghum seedlings or a suitable artificial diet. Thus, there is a need to standardize artificial diet for shoot fly to enable the testing of these parasitoids across different growth stages, as well as mass multiplication and inundative releases on a large scale for biological control of the insect. With the advent of novel biotechnological tools, as well as the availability of new and potent Bt endotoxins (Cry II and Cry IV), which are effective for dipterans, future research efforts may have exciting potential in the development of transgenic sorghum plants resistant to shoot fly, but compatible with the natural enemy complex.

\section{ACKNOWLEDGEMENTS}

The authors express their grateful thanks to the library staff of ICRISAT for their help in providing periodical literature search, which greatly helped in the preparation of this paper.

\section{REFERENCES}

Abraham, C.C. \& Pradhan, S. (1976) Studies on developing races of Trichogramma australicum Girault suitable for high temperature, low humidity conditions. Madras Agricultural Journal 63, 550-556.

ADEsIYUN, A.A. (1981) Seasonal abundance of shoot flies infesting sorghum and their natural enemies in Samaru, Nigeria. Insect Science and its Application 2, 49-53.

AICSIP (All India Coordinated Sorghum Improvement Project) (1976) Progress Report 1975-76. All India Coordinated Sorghum Improvement Project. ICAR and Cooperative Agencies, New Delhi, India.

AICSIP (All India Coordinated Sorghum Improvement Project) (1977) Progress Report 1976-77. All India Coordinated Sorghum Improvement Project. ICAR and Cooperative Agencies, New Delhi, India.

AICSIP (All India Coordinated Sorghum Improvement Project) (1979) Progress Report 1978-79. All India Coordinated Sorghum Improvement Project. ICAR and Cooperative Agencies, New Delhi, India.

AICSIP (All India Coordinated Sorghum Improvement Project) (1980) Progress Report 1979-80. All India Coordinated Sorghum Improvement Project. ICAR and Cooperative Agencies, New Delhi, India.

AICSIP (All India Coordinated Sorghum Improvement Project) (1986) Progress Report 1985-86. All India Coordinated Sorghum Improvement Project. ICAR and Cooperative Agencies, New Delhi, India.

AICSIP (All India Coordinated Sorghum Improvement Project) (1987) Progress Report 1986-87. All India Coordinated Sorghum Improvement Project. ICAR and Cooperative Agencies, New Delhi, India.

AICSIP (All India Coordinated Sorghum Improvement Project) (1989) Progress Report 1988-89. All India Coordinated Sorghum Improvement Project. National Research Centre for Sorghum, Hyderabad, India.

AICSIP (All India Coordinated Sorghum Improvement Project) (1997) Progress Report 1996-97. All India Coordinated Sorghum Improvement Project. National Research Centre for Sorghum, Hyderabad, India.

Bailey, C.L. \& Chada, H.L. (1968) Spider populations in grain sorghum. Annals of the Entomological Society of America 61, 567-571.

Barry, D. (1972a) Notes on life history of a sorghum shoot fly, Atherigona varia soccata. Annals of the Entomological Society of America 65: 586-589.

BARRY, D. (1972b) Life history and other biological notes on sorghum shoot fly in East Africa, in Control of Sorghum Shoot fyy (Jotwani, M.G. \& Young, W.R., Eds). Oxford \& IBH Publishing Company, New Delhi, India, pp. 119-128.

Bellows, T.S., Van Driesche, R.G. \& Elkinton, J.S. (1992) Life-table construction and analysis in the evaluation of natural enemies. Annual Review of Entomology 37, 587-614.

Bleton, C.A. \& Fieuzet, L. (1939) Notes sur quelques insectes auxiliaries observes dans la region de Fes. Bulletin Societe Science et Natural Maroc 19, 57-65.

Bleton, C.A. \& Fieuzet, L. (1943) Sur la presence et la biologie au Maroc d'Atherigona soccata Rondani, Diptere parasite du sorghum cultive. Bulletin Societe de Horticulture Afrique N. 34, 112-117.

Borad, P.K. \& MitTaL, V.P. (1983) Assessment of losses caused by pest complex to sorghum hybrid, CSH 
5, in Crop Losses due to Insect Pests, Special Issue of Indian Journal of Entomology (KRISHNAMURTHY RAO, B.H. \& Murthy, K.S.R.K., Eds). Entomological Society of India, Rajendranagar, Hyderabad, Andhra Pradesh, India, pp. 271-278.

Breniere, J. (1972) Sorghum shoot fly in West Africa, in Control of Sorghum Shoot fly (Jotwani, M.G. \& Young, W.R., Eds). Oxford \& IBH Publishing Company, New Delhi, India, pp. 129-136.

Buchanan, R.E. \& GibBons, N.E. (1974) Bergey's Manual of Determinative Bacteriology. Williams \& Wilkins, Baltimore, Maryland, USA.

CHopde, P.R. (1978) Evaluation of tolerant types of sorghum varieties and hybrids to shoot fly, Atherigona soccata Rond. (1974-77). Marathwada Agricultural University, Parbhani, India.

CIE (Commonwealth Institute of Entomology) (1973) Sorghum shoot fly, Atherigona varia soccata Rond. (Diptera: Muscidae). Distribution of Maps of Pests-Series A (Agriculture), No. 311. Commonwealth Institute of Entomology, London, UK.

DeEming, J.C. (1971) Some species of Atherigona Rondani (Diptera: Muscidae) from Northern Nigeria, with special reference to those injurious to cereal crops. Bulletin of Entomological Research 61, 133-190.

Deeming, J.C. (1983) Atherigona spp. (Dipt., Muscidae) as prey of Dasyproctus bipunctatus Lepeletier and Brulle (Hym., Sphecidae) in Uganda. Entomologists Monthly Magazine 119, 83.

Del Bene, G. (1986) Note sur la biologia di Atherigona soccata Rondani (Diptera, Muscidae) in Toscano e Lazio. Redia LXIX, 47-63.

Delobel, A.G.L. (1984) Etude des facteurs determinant l'abondance des populations de la mouche du sorgho, Atherigona soccata Rondani (Dipteres, Muscidae). These de Doctorat d'Etats, Universite de Paris Sud, Centre d'Orsay, ORSTOM, France, $127 \mathrm{pp}$.

Delobel, A.G.L. \& Lubega, M.C. (1984) Rainfall as a mortality factor in the sorghum shoot fly, Atherigona soccata Rondani (Diptera: Muscidae) in Kenya. Insect Science and its Application 2, 67-71.

Descamps, M. (1957) Contribution a l'altitude des dipteres Diopsidae nuisibles au riz dans le NordCameroun. Journal de Agriculture Tropicale et Botanic Applique 4, 83-93.

Doumbia, Y.O. \& Gahukar, R.T. (1986) Atherigona soccata Rondani and other flies harmful to sorghum in Mali. Agronomie Tropicale 41, 170-172.

FAO (Food and Agriculture Organization) (1999) FAO Handbook of Agricultural Statistics. Food and Agriculture Organization, Rome, Italy.

Feijen, H.R. \& Schulten, G.G.M. (1981) Egg parasitoids (Hymenoptera: Trichogrammatidae) of Diopsis macrophthalma (Diptera: Diopsidae) in Malawi. Netherlands Journal of Zoology 31, 381-417.

Forel, A. (1920) Les Fourmis de la Suisse. La Chaux-de-Fonds, Imprimeria Cooperative.

GAhukAR, R.T. (1985) Some species of Atherigona (Diptera: Muscidae) reared from Gramineae in Senegal. Annals of Applied Biology 106, 399-403.

GeEring, Q.A. (1953) The sorghum midge, Contarinia sorghicola (Coq.) in East Africa. Bulletin of Entomological Research 44, 363-366.

Gilstrap, F.E. (1980) Biological control of sorghum pests, in Elements of Integrated Control of Sorghum Pests. FAO Plant Production \& Protection Paper No. 19. Food and Agriculture Organization, Rome, Italy, pp. 54-98.

GilstraP, F.E. (1985) Concepts for biological control of arthropods attacking sorghum, in Proceedings of the International Sorghum Entomology Workshop, 15-21 July, 1984, Texas A\&M University, College Station, Texas, USA. International Crops Research Institute for the Semi-Arid Tropics (ICRISAT), Patancheru, Andhra Pradesh, India, pp. 403-412.

Graham, De V., M.W.R. (1987) A reclassification of the European Tetrastichinae (Hymenoptera: Eulophidae), with a revision of certain genera. Bulletin of British Museum of Natural History (London), Entomology Series 55, 55-69.

HalsteAd, J.A. (1990) Revision of Hockeria Walker in the Nearctic region with descriptions of males and five new species (Hymenoptera: Chalcididae). Proceedings of the Entomological Society of Washington 92, 619-640.

Hemer, M. (1960) On the bionomics, economic importance and control of Oscinella frit on barley. Part II. From investigations in Westphalia in 1948-52. Zeitschrift fur Angewandte Entomologie 46, 71-119.

Holldobler, B. \& Wilson, E.O. (1990) The Ants. Harvard University Press, Cambridge, Massachusetts, USA.

Hugar, P. S., Jai Rao, K. \& Lingappa, S. (1990) Effect of chilling on hatching and parasitism of eggs of Corcyra cephalonica (Stainton) by Trichogramma chilonis (Ishii). Entomon 15, 49-52.

Humber, R.A. \& SoPER, R.S. (1986) USDA-ARS Collection of Entomopathogenic Fungal Cultures Catalogue of Strains. USDA-ARS Plant Protection Research Unit, Boyce Thompson Institute of Plant Research, Cornell University, Ithaca, New York.

ICIPE (International Centre of Insect Physiology and Ecology) (1982) ICIPE Ninth Annual Report 1981. International Centre of Insect Physiology and Ecology, Nairobi, Kenya.

ICRISAT (International Crops Research Institute for the Semi-Arid Tropics) (1980) ICRISATAnnual Report 1979-80. International Crops Research Institute for the Semi-Arid Tropics (ICRISAT), Patancheru, Andhra Pradesh, India.

ICRISAT (International Crops Research Institute for the Semi-Arid Tropics) (1982) ICRISAT Annual 
Report 1981. International Crops Research Institute for the Semi-Arid Tropics (ICR ISAT), Patancheru, Andhra Pradesh, India.

ICRISAT (International Crops Research Institute for the Semi-Arid Tropics) (1992) The Medium Term Plan. Vol. 1. International Crops Research Institute for the Semi-Arid Tropics, Patancheru, Andhra Pradesh, India (Limited distribution).

Jai Rao, K., Thontadarya, T.S. \& Rangadhamaiah, K. (1980) New record of Trichogrammatoidea bactrae Nagaraja (Hym.: Trichogrammatidae) as an egg parasite of the castor semilooper, Achaea janata L. (Lep.: Noctuidae). Current Science 49, 800.

Jai RaO, K., Thontadarya, T.S. \& Suhas, Y. (1987) Trichogrammatoidea bactrae Nagaraja-A new egg parasitoid of sorghum shoot fly, Atherigona soccata Rondani. Current Science 56, 283.

JALALI, S.K. \& Singh, S.P. (1992) Differential response of four Trichogramma species to low temperatures for short-term storage. Entomophaga 37, 159-165.

JALALI, S.K. \& Singh, S.P. (1993) Superior strain selection of the egg parasitoid, Trichogramma chilonis Ishii-biological parameters. Journal of Biological Control 7, 57-60.

Jotwani, M.G. (1978) Investigations on Insect Pests of Sorghum and Millet with Special Reference to Host Plant Resistance. Final Technical Report (1972-77). Division of Entomology, Indian Agricultural Research Institute, New Delhi, India.

Jotwani, M.G. (1981) Integrated approach to the control of the sorghum shoot fly. Insect Science and its Application 2, 123-127.

Jotwani, M.G. (1982) Factors reducing sorghum yield-insect pests, in Sorghum in the Eighties. Proceedings of the International Symposium, 2-7 November 1981, International Crops Research Institute for the Semi-Arid Tropics (ICR ISAT), Patancheru, Andhra Pradesh, India, pp. 251-255.

Jotwani, M.G. (1983) Losses due to shoot fly in high yielding sorghum cultivars, in Crop Losses Due to Insect Pests, Special Issue of Indian Journal of Entomology (Krishnamurthy Rao, B.H. \& Murthy, K.S.R.K., Eds), Entomological Society of India, Rajendranagar, Hyderabad, India, pp. 213-220.

Jotwani, M.G. \& Young, W.R. (Eds.) (1972) Control of Sorghum Shoot Fly. Oxford \& IBH Publishing, New Delhi.

Jotwani, M.G., Young, W.R. \& TeEtes, G.L. (1980) Elements of Integrated Control of Sorghum Pests. FAO Plant Production and Protection Paper No. 39. Food and Agriculture Organization, Rome, Italy.

Kishore, P., Jotwani, M.G., Sukhani, T.R. \& Srivastava, K.P. (1977a) Some new parasites recorded on sorghum shoot fly, Atherigona soccata (Rondani). Sorghum Newsletter 20, 57.

Kishore, P., Jotwani, M.G., Sukhani, T.R. \& Srivastava, K.P. (1977b) New parasites recorded on the sorghum shoot fly, Atherigona soccata Rondani. Current Science 46, 495-496.

Kundu, G.G., Kishore, P. \& Jotwani, M.G. (1971a) Parasites of Atherigona varia soccata Rondani. Entomologists' Newsletter 1, 14.

Kundu, G.G., Kishore, P. \& Jotwani, M.G. (1971b) Host record of Callitula bipartitus Farooqui (MS). Entomologists' Newsletter 1, 20.

Kundu, G.G., Kishore, P. \& Jotwani, M.G. (1971c) New records of parasites of the sorghum shoot fly, Atherigona soccata Rondani, in Investigations on Insect Pests of Sorghum and Millets, 1965-70. (PradHan, S., Ed.). Division of Entomology, Indian Agricultural Research Institute, New Delhi, India, pp. 145-146.

LEUSCHNER, K. (1985) Sorghum entomology research: programs and the need in the developing world, in Proceedings of the International Sorghum Entomology Workshop, 15-21 July, 1984, Texas A\&M University, College Station, Texas, USA. International Crops Research Institute for the Semi-Arid Tropics (ICRISAT), Patancheru, Andhra Pradesh, India, pp. 13-20.

MaitaI, W.M. (1958) Annotated list of insects associated with the sweet potato (Ipomoea batatas). East African Agriculture Journal 23, 290-291.

Mandal, S.K. \& Somchoudhury, A.K. (1991) Occurrence of ecotypes in Trichogramma chilonis Ishii (Trichogrammatidae: Hymenoptera). Journal of Entomological Research 15, 266-270.

Mani, M.S. (1941) Studies on Indian parasitic Hymenoptera I. Indian Journal of Entomology 3, 25-36.

MANINDER, S. \& VARMA, G.C. (1980) Effect of ultra-violet light and sub-zero temperature on the eggs of Corcyra cephalonica Stainton for emergence and progeny development of Trichogramma brasiliensis Ashmead. Science and Culture 46, 300-301.

Meksongsee, B., Chawanapong, M., Sangkasuwan, U. \& Poonyathaworn, P. (1981) The biology and control of sorghum shoot fly, Atherigona soccata Rondani in Thailand. Insect Science and its Application 2, 111-116.

Mote, U.N. (1986) Correlation between deadhearts caused by shoot fly, Atherigona soccata Rondani and the yield of sorghum hybrids. Indian Journal of Entomology 48, 356-357.

Nagaraja, H. (1978) Studies on Trichogrammatoidea (Hymenoptera: Trichogrammatidae). Oriental Insects 12, 489-500.

NAGaRKatTI, S. (1979) Experimental comparison of laboratory reared vs wild-type Trichogramma chilonis (Hym.: Trichogrammatidae). II. Tolerance of non-optimal temperatures. Entomophaga 24, 417-424.

Nagarkatti, S. \& Nagaraja, H. (1977) Biosystematics of Trichogramma and Trichogrammatoidea species. Annual Review of Entomology 22, 157-176.

Nagarkatti, S. \& Nagaraja, H. (1978) Experimental comparison of laboratory reared vs wild type 
Trichogramma confusum (Hym.: Trichogrammatidae). I. Fertility, fecundity and longevity. Entomophaga 23, $129-136$.

NagarkatTi, S. \& Nagaraja, H. (1979) The status of Trichogramma chilonis Ishii (Hym.: Trichogrammatidae). Oriental Insects 13, 115-118.

Odhiambo, T.R. (Ed.) (1981) The biology, ecology, and control of the sorghum shoot fly, Atherigona soccata Rondani. Insect Science and its Application 2, 1-127.

Pont, A.C. (1972) The oriental species of Atherigona Rondani, in Control of Sorghum Shoot Fly (JotwanI, M.G. \& Young, W.R., Eds). Oxford \& IBH Publishin, New Delhi, India, pp. 27-104.

Rahim, A. (1990) Biocontrol of sorghum shoot fly. Quarterly Newsletter (Asia \& Pacific Plant Protection Commission) 31, 21.

RaI, S., Jotwani, M.G. \& Jha, D. (1978) Economic injury level for sorghum shoot fly, Atherigona soccata Rond. on sorghum. Indian Journal of Entomology 40, 126-133.

RaINA, A.K. (1981) Movement, feeding behavior and growth of larvae of the shoot fly, Atherigona soccata. Insect Science and its Application 2, 77-81.

Raodeo, A.K., Tikar, D.T. \& Chundurwar, R.D. (1972) Record of natural parasites of sorghum shoot fly, Atherigona varia soccata Rond. Current Science 41, 430-431.

RawaT, R.R. \& SAHU, H.R. (1968) New records of Tetrastichus nyemitawus Rohwer (Hymenoptera: Eulophidae) as a parasite of Atherigona sp., the wheat stem fly in Madhya Pradesh. Indian Journal of Entomology 30, 319.

Reddy, K.V.S. \& Davies, J.C. (1978) A predaceous mite on the eggs of sorghum shoot fly, Atherigona soccata (Diptera: Muscidae) at Hyderabad. Acarology Newsletter 6, 9.

REDDY, K.V.S. \& Davies, J.C. (1979) Pests of sorghum and pearl millet and their parasitoids and predators recorded at ICRISAT center up to August, 1979. Cereal Entomology Progress Report 2. International Crops Research Institute for the Semi-Arid Tropics (ICRISAT), Patancheru, Andhra Pradesh, India.

Rohwer, S.A. (1921) Descriptions of new chalcidid flies from Coimbatore (S. India). Annual Magazine, Natural History 7, 123-135.

Sharma, D.R. (1968) Behaviour of stem fly, Atherigona varia soccata Rond. under different environmental conditions and its reaction on different sorghum varieties. Journal of PG School (IARI) 6, 63.

Shivpuje, P.R. (1977) Record of new natural parasites of sorghum shoot fly, Atherigona varia soccata Rondani (Diptera: Anthomyiidae). Entomology Newsletter 88, 52.

Shivpuje, P.R. \& ChOPDe, P.R. (1976) Record of a natural parasite of the sorghum shoot fly (A. varia soccata Rond.). Sorghum Newsletter 19, 56.

Singh, S.P., Jalali, S.K., Bhumannavar, B.S., Baktavatsalam, N. \& PushPalatha, N.A. (1994) Production and Use of Trichogrammatid Egg Parasitoids. Project Directorate of Biological Control. Technical Bulletin No. 11. Indian Council of Agricultural Research, Bangalore, India.

Singh, B.U. \& Rana, B.S. (1986) Resistance in sorghum to the shoot fly, Atherigona soccata Rondani. Insect Science and its Application 7, 577-587.

SinHA, R.N. (1966) Aeroglyphus robustus, a pest of stored grain. Journal of Economic Entomology 59, 686-688.

Sмiтh, M.R. (1961) Annual Report 1959-60. West African Cocoa Research Institute, Nigeria.

TALEY, Y.M. (1978) A note on the parasite complex of sorghum shoot fly, Atherigona soccata Rondani. Paper presented at the VIII Annual AICSIP Workshop, 17-19 April, 1978, University of Agricultural Sciences, Dharwad, India, 4 pp.

TALEY, Y.M. (1979) Bionomics and natural control of Atherigona soccata and Chilo partellus pests of hybrid sorghum together with the effect of some modern insecticides disturbing their natural balance. Ph.D. thesis, Punjabrao Krishi Vidyapeeth, Akola, India.

Taley, Y.M. \& Thakare, K.R. (1977) Parasites of sorghum shoot fly, Atherigona soccata Rondani. Sorghum Newsletter 20, 30.

TAley, Y.M. \& ThaKare, K.R. (1979) Biology of seven new hymenopterous parasitoids of Atherigona soccata (Rondani). Indian Journal of Agricultural Sciences 49, 344-354.

Thongsanga, S. (1985) Ecology of sorghum shoot fly (Atherigona soccata Rondani) (Diptera: Muscidae). $\mathrm{PhD}$ thesis, Kasetsart University, Bangkok, Thailand, $176 \mathrm{pp}$.

Venturi, F. (1940) Contribute alla conoscenza dell'Entomofauna delle Graminaceae VI. Redia 18, 27-70.

YounG, W.R. (1981) Fifty-five years of research on the sorghum shoot fly. Insect Science and 'its Application 2, 3-9.

ZoNGO, J.O. (1992) Integrated pest management approach for the sorghum shoot fly,Atherigona soccata Rondani (Diptera: Muscidae), in Burkina Faso. PhD thesis, McGill University, Montreal, Quebec, Canada.

ZongO, J.O. (1995) Biological control of the sorghum shoot fly, Atherigona soccata: Seventy-one years of research, in Beneficial African Insects: A Renewable Natural Resource. Proceedings of the 10th Meeting and Scientific Conference of the African Association of Insect Scientists (ODInDo, M.O., Ed.), 10-15 September, 1993, Mombasa, Kenya, pp. 31-36.

Zongo, J.O., Vincent, C. \& Stewart, R.K. (1993a) Effects of intercropping sorghum-cowpea on natural enemies of the sorghum shoot fly, Atherigona soccata Rondani (Diptera: Muscidae) in Burkina Faso. Biological Agriculture and Horticulture 9, 201-213. 
Zongo, J.O., Vincent, C. \& Stewart, R.K. (1993b) Biology of Trichogrammatoidea simmondsi (Hym: Trichogrammatidae) on sorghum shoot fly, Atherigona soccata (Dipt.: Muscidae) eggs. Entomophaga 38, 267-272.

Zongo, J.O., Vincent, C. \& Stewart, R.K. (1993c) Parasitism of sorghum shoot fly, Atherigona soccata Rondani (Diptera, Muscidae) by Neotrichoporoides nyemitawus Rohwer (Hymenoptera, Eulophidae). Insect Science and its Application 14, 637-642.

Zongo, J.O., Vincent, C. \& Stewart, R.K. (1993d) Effects de la bi-culture sorgho-niebe sur les ennemis naturels de la mouche des pousses du sorgho, Atherigona soccata (Diptera: Muscidae) au Burkina Faso. Sahel PV Info 58, 8-12. 
Copyright of Biocontrol Science \& Technology is the property of Carfax Publishing Company and its content may not be copied or emailed to multiple sites or posted to a listserv without the copyright holder's express written permission. However, users may print, download, or email articles for individual use. 